\title{
GEOMARINE 1: AUTONOMOUS USV (UNMANNED SURFACE VEHICLE) UNTUK MENDUKUNG SURVEI HIDRO-OCEANOGRAFI
}

\author{
Danar Guruh Pratomo ${ }^{1}$, Andi Rahmadiansah ${ }^{2}$, Mokhamad Nur Cahyadi ${ }^{1}$, Ira Mutiara Anjasmara ${ }^{1}$, \\ Khomsin ${ }^{1}$, Fajar Setio Adi $^{3}$ \\ ${ }^{1}$ Departemen Teknik Geomatika, FTSLK-ITS, Kampus ITS Sukolilo, Surabaya, 60111, Indonesia, \\ ${ }^{2}$ Departemen Teknik Fisika, FTI-ITS, Kampus ITS Sukolilo, Surabaya, 60111, Indonesia, \\ ${ }^{3}$ PT. Geotronix Pratama Indonesia, Jakarta, 10210, Indonesia \\ e-mail:*1guruh@geodesy.its.ac.id
}

\begin{abstract}
Abstrak
Survei hidro-oceanografi dilakukan untuk mengetahui karakteristik fisik dari suatu perairan. Salah satu kegiatan yang termasuk dalam survei hidro-oceanografi adalah penentuan kedalaman dan pencitraan bentuk topografi dasar laut. Pada umumnya, survei tersebut dilakukan dengan menggunakan wahana apung (kapal) yang relatif besar yang minimal dapat menampung surveyor dan pengemudi kapal. Wahana apung konvensional tersebut memiliki keterbatasan dalam bermanuver, terutama di daerah perairan yang dangkal dan sempit. Keterbatasan dalam mobilisasi, juga menjadi kendala ketika wahana apung konvensional akan digunakan untuk survei di area perairan pedalaman (sungai, waduk, dam, bekas galian tambang).

Geomarine 1 merupakan solusi alternatif untuk melakukan survei hidro-oseanografi di daerah perairan dimana penggunaan wahana apung konvensional tidak dapat digunakan secara efektif. Geomarine 1 merupakan wahana apung tanpa awak (Unmanned Surface Vehicle) yang memiliki sistem mandiri (autonomous). Wahana apung tanpa awak ini dilengkapi dengan sensor anti tabrakan (collision avoidance) dan fungsi kembali ke titik awal (home return) apabila survei sudah selesai dilakukan ataupun pada saat baterai akan habis. Sensor survei hidro-oceanografi yang terdapat pada wahana ini merupakan kombinasi sensor akustik dan optik. Sensor akustik digunakan untuk penentuan kedalaman dan pencitraan topografi dasar laut, sedangkan sensor optik digunakan untuk perekaman kondisi fisik perairan secara visual.
\end{abstract}

Kata kunci : Autonomous, Wahana apung tanpa awak, Hidro-Oseanografi, Topografi Dasar Laut

\section{PENDAHULUAN}

Salah satu kegiatan survei hidro-oceanografi adalah penentukan kedalaman dan pencitraan dasar perairan. Kegiatan ini sering disebut dengan survei bathimetri. Survei batimetri pada umumnya dilakukan pada daerah perairan yang luas dan relatif dalam seperti lepas pantai dengan mengikuti lajur pemeruman yang telah ditentukan. Kegiatan ini membutuhkan wahana apung yang dimensinya relatif besar yang mampu untuk membawa alat survei batimetri seperti echosounder dan alat untuk penentuan posisi horisontal kapal serta personel yang dibutuhkan. Survei bathimetri digunakan untuk mendukung pekerjaan di bidang kelautan seperti penentuan lajur pelayaran, perencanaan bangunan tepi pantai, dan pertambangan minyak lepas pantai. Survei batimetri umumnya dilakukan pada daerah perairan luar (pesisir dan laut lepas). Sedangkan untuk perairan pedalaman (danau, waduk, dam, atau bekas galian tambang) survei bathimetri jarang sekali dilakukan karena keterbatasan mobilisasi wahana apung konvensional.

Keterbatasan yang dimiliki oleh wahana apung konvensional dalam melakukan survei di perairan pedalaman dapat diatasi dengan adanya kapal apung tanpa awak (Unmanned Surface Vessel-USV) yang mudah untuk dibawa dan dapat bergerak lebih fleksibel. Pada penelitian ini wahana apung tanpa awak dibangun dengan memanfaatkan sensorsensor yang digunakan untuk survei bathimetri, yaitu sensor untuk penentuan posisi, kedalaman, dan penampakan dasar perairan.

Wahana apung yang dibangun pada penelitian ini, Geomarine 1, mengadopsi model kapal katamaran dengan satu motor listrik dan satu baling- baling (beserta pendingin mesin). Wahana ini juga akan dilengkapi dengan dua kamera: satu kamera berada di depan kapal untuk memantau kondisi di depan 
kapal dan satu kamera berada di lambung kapal yang terhubung dengan GPS di atasnya. Selain itu wahana ini juga dilengkapi dengan kamera bawah air ini akan memberikan informasi mengenai situasi di bawah permukaan air.

Geomarine 1 membawa sensor akustik single beam echosounder dan side scan sonar untuk yang terintegrasi untuk mengetahui kedalaman dasar perairan dan kondisi topografi dasar perairan tersebut. Berdasarkan data dari side scan sonar hasil akuisisi dengan wahana apung tanpa awak tersebut, pemahaman tentang topografi dasar perairan dan distribusi sedimen di perairan tersebut dapat dipetakan. Pembangunan kapal tanpa awak ini diharapkan dapat menunjang pembangunan wilayah pesisir.

\section{METODE}

USV Geomarine 1 yang dibangun pada penelitian ini menggunakan sistem autonomous, yang memungkinkan wahana tanpa awak ini dapat bergerak secara mandiri. Pada penelitian ini, terdapat beberapa tahapan pembangunan: [a] identifikasi penentuan karakteristik platform AUSV, [b] perancangan sistem meliputi perangkat keras dan lunak, [c] pembuatan dan perakitan komponen sistem serta [d] melakukan pengujian di perairan Indonesia, terutama perairan dalam (bendungan, danau, bekas galian tambang, dan dam).

Pada subbab berikut akan dijelaskan mengenai tahapan penelitian yang dilakukan pada penelitian ini.

\section{Penentuan Ukuran Kapal dan Bentuk Lambung}

Bentuk lambung kapal sangat mempengaruhi terhadap kecepatan serta stabilitas pada kapal. Optimasi ukuran utama kapal dilakukan untuk mencari ukuran utama dari wahana USV pada penelitian ini. Sebagai pendekatan pertama, karakteristik gelombang transversal diasumsikan sama dengan gelombang sinus di mana panjang gelombang, Lw (feet), terkait dengan kecepatan, $\mathrm{Ck}$ (knot) dengan persamaan berikut (Ni Made dan Suwardhi (2014).:

$C k=1.3 \sqrt{L w}$

SLR (Side Length Ratio) kapal sangat tergantung pada panjang lambung dan kecepatan di air. Hubungan antara panjang gelombang yang dihasilkan oleh kapal (Lw) dan beban panjang garis air (LwI) sebagai fungsi dari SLR dapat dilihat pada persamaan 2 .

$\frac{L w}{L w l}=\frac{S L R^{2}}{1.80}$

\section{Stabilitas Wahana}

Stabilitas wahana adalah kemampuan kapal untuk menegak kembali sewaktu kapal pada saat diapungkan, tidak miring kekiri atau kekanan, demikian pula pada saat berlayar, disebabkan oleh adanya pengaruh luar yang bekerja padanya pada saat kapal diolengkan oleh ombak atau angin, kapal dapat tegak kembali (Newman, 2010). Stabilitas awal sebuah kapal adalah kemampuan dari kapal itu untuk kembali kedalam kedudukan tegaknya semula sewaktu kapal miring pada sudut-sudut kecil ( \pm 60 derajat ). Pada stabilitas awal sebuah wahana apung, titik-titik yang menentukan besar kecilnya nilai-nilai stabilitas awal adalah sebagai berikut :

a. Titik Berat Kapal (G)

Titik di kapal yang merupakan titik tangkap dari resultante semua gaya berat yang bekerja di kapal itu, dan dipengaruhi oleh konstruksi kapal. arah gaya kerja titik berat kapal adalah tegak lurus ke bawah.

b. Titik Tekan Kapal atau Titik Apung Kapal (B)

Titik stabilitas kapal (centre of buoyency) sebuah titik di kapal yang merupakan titik tangkap resultan semua gaya tekanan ke atas air yang bekerja pada bagian kapal yang terbenam di dalam air. Arah bekerjanya gaya tekan adalah tegak lurus ke atas.

c. Titik Metasentrum (M) Stabilitas Kapal

Titik di kapal yang merupakan titik putus yang busur ayunannya adalah lintasan yang dilalui oleh titik tekan kapal.

\section{Perhitungan Tahanan dan Tekanan}

Tahanan kapal (resistance) pada suatu kecepatan adalah gaya fluida yang bekerja pada kapal demikian rupa sehingga melawan gerakan kapal tersebut. Tahanan tersebut sama dengan komponen gaya fluida yang bekerja sejajar dengan sumbu gerakan kapal. Rumus empiris untuk perhitungan tahanan gesek $\left(R_{f}\right)$ dapat dilihat pada formula berikut (Alberto dan Pierluigi, 2012).

$R_{f}=C_{f}\left(\frac{1}{2} \rho V^{2}\right) s$

dimana,

$C_{f}=$ koefisien tahanan gesek

$\rho=$ massa jenis 
$V=$ kecepatan kapal

$s=$ luas permukaan basah kapal

Tahap selanjutnya adalah proses pembuatan wahana apung tanpa awak model katamaran. Model ini memiliki dua lambung: sisi port dan sisi starboard. Masing-masing lambung memiliki lima sekat agar USV memiliki ketahanan terhadap beban yang cukup berat dan keseimbangan dalam melakukan manufer yang relatif baik (Prabhu, 2016). .

Setelah proses pembuatan USV model katamaran selesai, proses selanjutnya adalah penambahan sistem kemudi, baling-baling dan sistem kelistrikan lainnya, termasuk sumber daya berupa aki kering. Tahap selanjutnya adalah pengujian kapal yang berfokus kepada pengecekan wahana apung itu sendiri (kebocoran, daya apung dan daya angkut beban, kestabilan) dan sistem penggeraknya (motor, rudder, water pump, receiver, dan pengecekan sumberdaya listrik). Pada tahap ini juga akan dilakukan pengecekan remote control dengan wahana apakah tersambung dengan baik atau tidak.

Tahap selanjutnya adalah pemasangan alat-alat yang digunakan untuk keperluan survei hidrooceanografi yaitu antena GPS, transducer (singlebeam dan side scan sonar), dan processing unit.

Pada penelitian ini, alat yang digunakan untuk survei batimetri adalah Garmin Echomap 71sv. Setelah semua alat terpasang dengan baik, maka akan dilakukan percobaan di lapangan untuk mengetahui tingkat kelayakan dari sistem USV yang telah dibuat. Pengetesan akan dilakuan di beberapa tempat yang memiliki kondisi fisik yang berbeda (misal: danau dan sungai).

\section{Penentuan Cakupan Sistem Instrumentasi}

Tahapan pertama yang dilakukan yaitu menetukan cakupan sistem instrumentasi yang akan diaplikasikan ke wahana Autonomous-USV Geomarine 1. Sistem instrumentasi yang digunakan berupa mikrokotroler yang digunakan untuk beberapa fungsi, yaitu: [a] display kemudi, [b] pengolahan sensor autonomous dan sensor lingkungan, [c] penggerak kemudi sistem autonomous, serta [d] sistem multimedia.

Pada Gambar 1 dapat dilihat detil penggunaan mikrokontroler untuk multimedia, display, sensorsensor, dan aktuator kemudi. Dimana semua mikrontroler terintegrasi menggunakan komunikasi ethernet melalui router switch yang kedepannya bisa dikembangkan ke The Internet of Things (IoT).

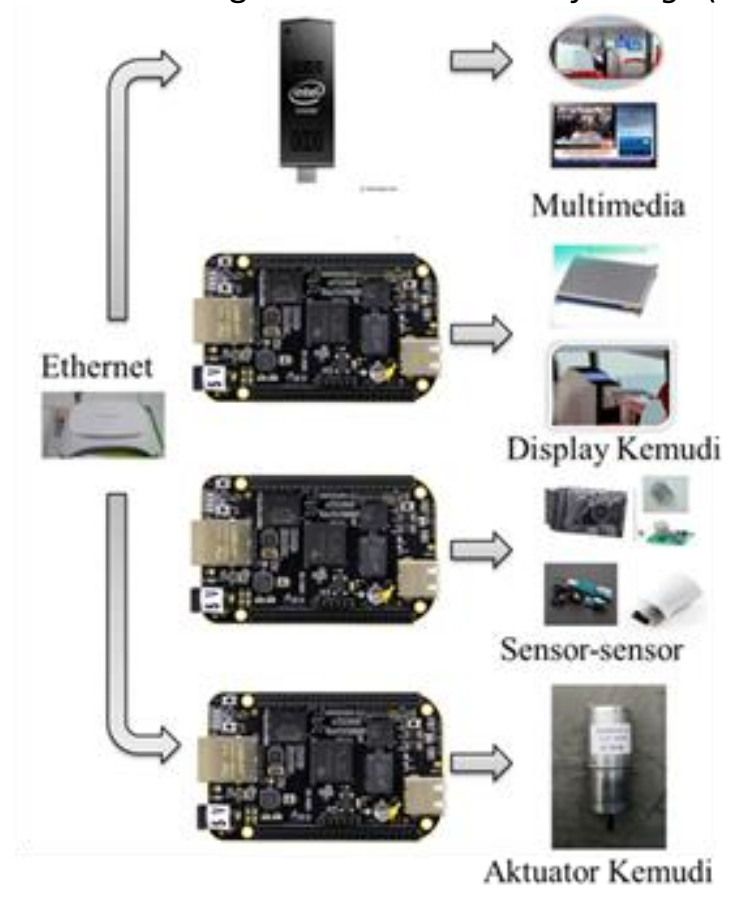

Gambar 1. Beberapa fungsi mikrokontroler yang digunakan pada penelitian ini

\section{Perancangan Sistem Informasi}

A-USV Geomarine 1 dirancang untuk bergerak secara mandiri (autonomous) tanpa dikendalikan oleh operator. Prinsip sistem yang dikembangkan adalah menggunakan prinsip Geographic Information System (GIS), beberapa informasi Global Navigation Satellite System (GNSS) untuk acuan awal koordinat berangkat. Kemudian sensor Inertial Measurement Unit (IMU) membaca arah dan kecepatan kapan sehingga bisa melakukan updating posisi kapal dari titik berangkat/acuan berdasarkan sensor GNSS sebelumnya. Metode yang digunakan selain berdasarkan sensor GNSS dan sensor IMU yaitu menggunakan gambar/citra kamera.

Metode image processing digunakan untuk mendukung metode GIS sekaligus dilengkapi kemampuan menghindari objek penghalang di depan kapal berdasarkan sensor ultrasonik yang ditempatkan di depan wahana. Gambar 2 memperlihatkan skema sistem otomatis yang digunakan pada A-USV Geomarine 1. 


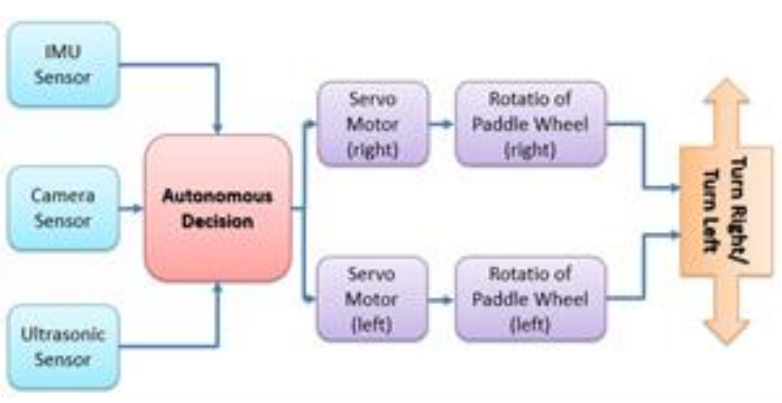

Gambar 2. Skema sistem otomatis kemudi A-USV Geomarine 1

Diagram alir untuk sistem kemudi autonomous dari A-USV berdasar sensor GPS dan IMU yang akan diterapkan dalam penelitian ini dapat dilihat pada Gambar 3.

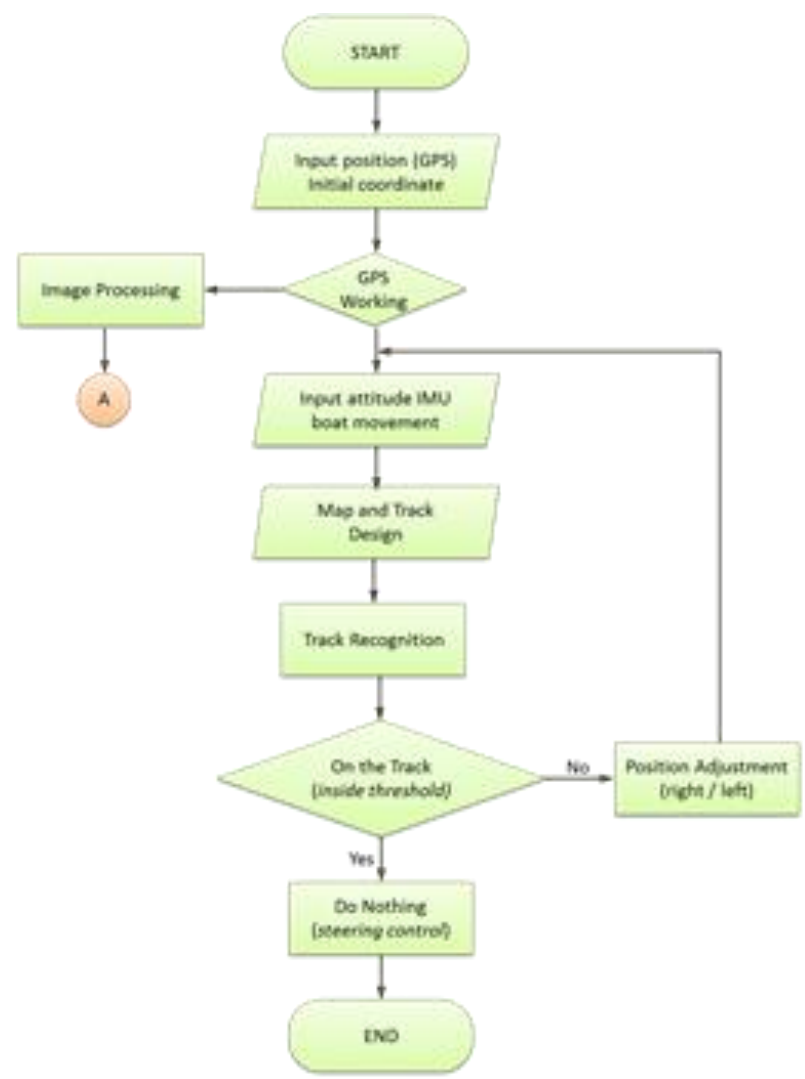

Gambar 3. Diagram alir sistem otomatis kemudi A-USV berdasar sensor GPS dan IMU

Sedangkan pada Gambar 4 dapat dilihat diagram alir sistem kemudi autonomous pada wahana ini yang didasarkan pada sensor kamera. Sistem autonomous yang lain bekerja berdasarkan masukan kamera yang ditempatkan di depan kapal dan menghadap ke depan. Gambar atau citra yang didapatkan menggunakan kamera diolah terlebih dahulu untuk menghilangkan bagian-bagian yang dianggap bukan objek utama dalam pengenalan (misal tepi sungai, air sungai, objek penghalang, dan sampah ukuran besar).

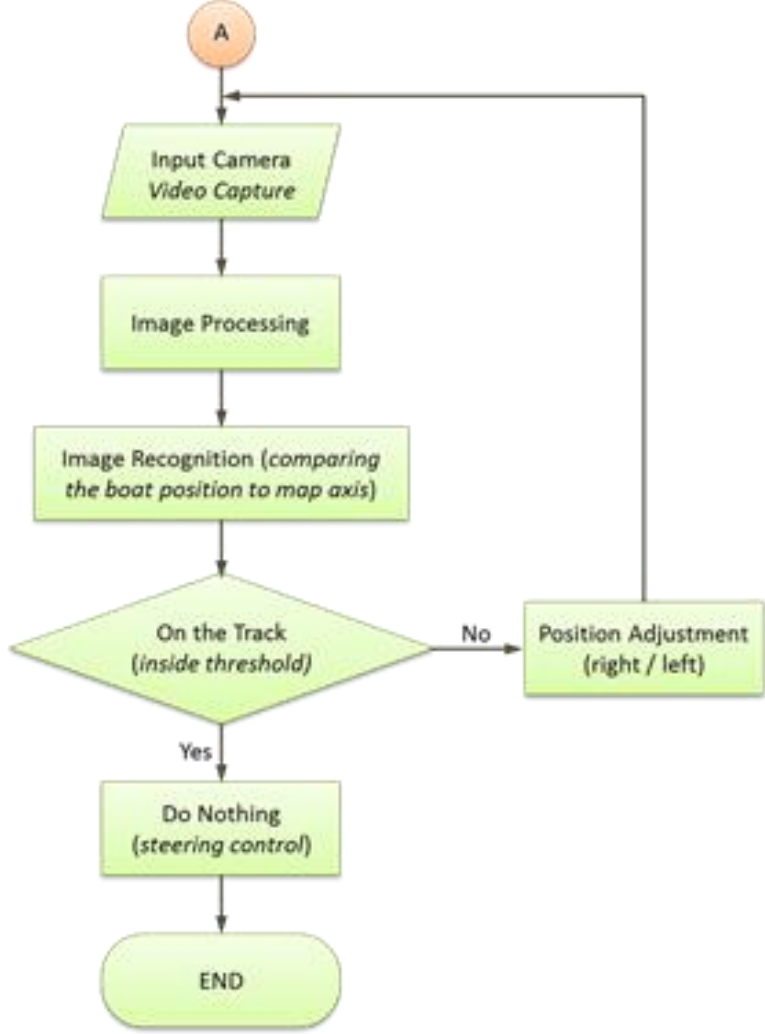

Gambar 4. Diagram alir sistem otomatis kemudi A-USV berdasarkan sensor kamera

Pada langkah pertama citra kamera dirubah menjadi citra greyscale dengan tujuan untuk mempercepat pemrosesan yang akan diolah oleh mikrokontroler. Setelah proses greyscale, dilakukan pembedaan bagian danau dan bagian bukan danau menggunakan edge detection. Untuk meningkatkan keakurasian maka sistem pengenalan mengacu data base peta garis pantai yang akan dilalui dan senantiasa diupdate (setiap citra kamera diolah). Proses image processing di mikrokontroler menggunakan OpenCV dan menggunakan bahasa Python.
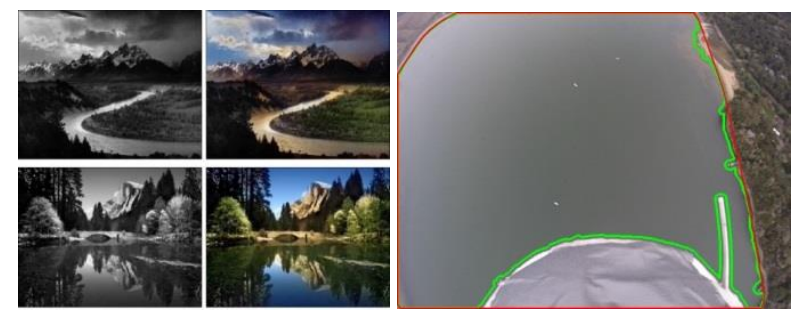

Gambar 5. Grayscale dan Edge Detection pada OpenCV 
Sistem kontrol dari A-USV Geomarine 1 dilengkapi dengan kemampuan menghindari objek yang terletak di depan kapal. Ketika objek di depan kapal dikenali oleh sensor ultrasonik maka kapal akan bergeser ke arah dimana sisi sungai yang masih cukup untuk dilewati. Secara keseluruhan algoritma disimpan di mikrokontroler. Pada Gambar 6 dapat dilihat metode yang diterapkan pada A-USV Geomarine 1 dalam menghindari objek-objek berbahaya (obstacles) yang berada di depan kapal.

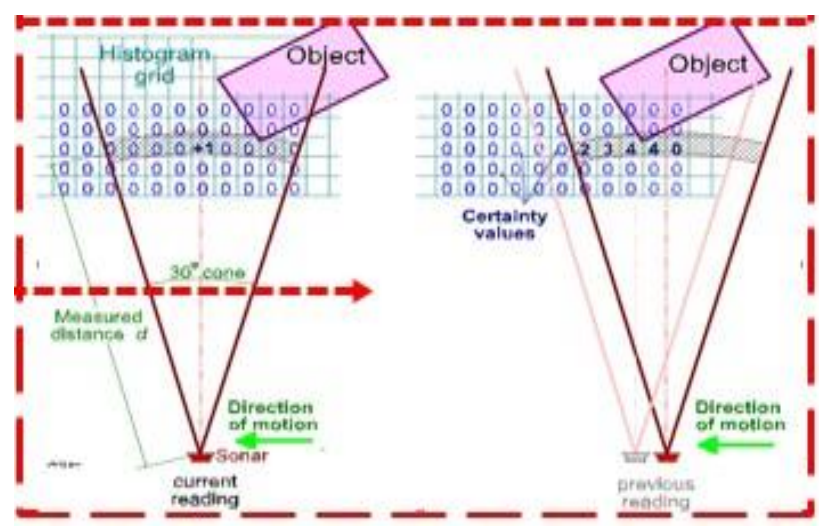

Gambar 6. Metode Menghindari Objek di Depan Kapal dengan Sensor Ultrasonik

\section{HASIL DAN PEMBAHASAN}

Sistem autonomous yang diterapkan pada A-USV Geomarine 1 berbasis pengolahan citra digital. Tahapannya antara lain mengambil gambar dari kamera, merubah format gambar, beberapa filter gambar, dan pengenalan gambar. Pembahasan terhadap hasil penelitian dan pengujian yang diperoleh disajikan secara kualitatif maupun kuantitatif.

\section{Pengambilan Gambar}

Untuk mengetahui kapan saatnya kapal merubah haluannya/belok, pada penelitian ini digunakan kamera yang dihubungkan ke Single Board Computer (SBC).

Aplikasi pengenalan objek yang digunakan dibuat menggunakan bahasa pemrograman Python dengan memanfaatkan library yang sudah ada yaitu OpenCV. Pada penelitian ini objek yang ditangkap kamera masih dalam format warna aslinya yaitu Red-Green-Blue (RGB). Penelitian ini menggunakan objek bola berwarna hijau sebagai penanda tujuan yang akan ditempuh kapal.

Untuk menentukan jarak objek tepat di depan kapal dan di depan yang bergeser ke samping berdasarkan diameter bola warna. Pada Gambar 7 dapat dilihat objek yang digunakan untuk validasi dalam penentuan jarak.

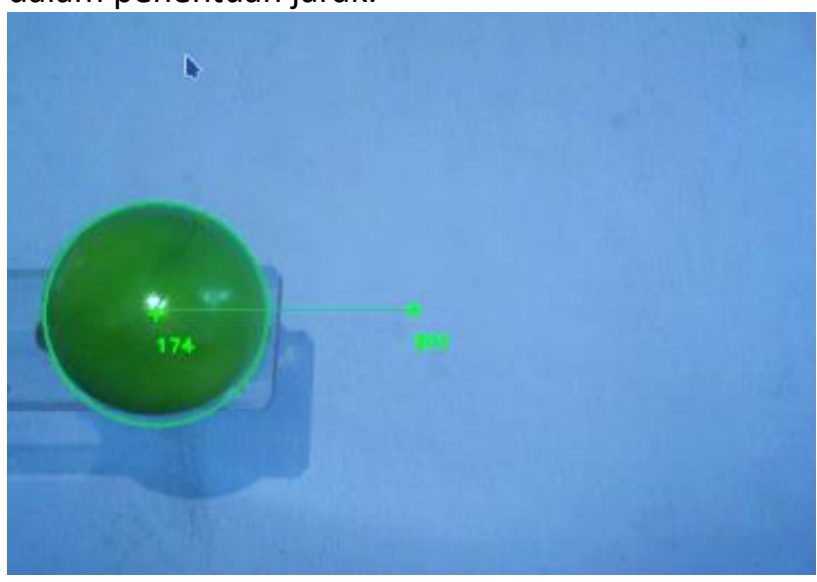

Gambar 7. Objek Bola dalam Format RGB

Untuk mengetahui jarak antara kamera dan objek bola, dihitung jumlah piksel yang divalidasi dengan jarak yang sebenarnya di lapangan. Hasil kalibrasi jarak obyek tepat di depan kapal sejauh $30 \mathrm{~cm}$ didapatkan jarak pada kamera sejauh 142,6 piksel (Tabel 1) dan jarak sejauh $60 \mathrm{~cm}$ didapatkan 74,8 piksel (Tabel 2).

Tabel 1. Hasil kalibrasi pada jarak depan $30 \mathrm{~cm}$

\begin{tabular}{cccc}
\hline $\begin{array}{c}\text { Data } \\
\text { ke-n }\end{array}$ & $\begin{array}{c}\text { Jarak Depan } \\
\text { Obyek }(\mathbf{c m})\end{array}$ & $\begin{array}{c}\text { Jarak Image } \\
\text { (piksel) }\end{array}$ & $\begin{array}{c}\text { Faktor } \\
\text { Pengali }\end{array}$ \\
\hline 1 & 30 & 144 & 0,208 \\
2 & 30 & 143 & 0,210 \\
3 & 30 & 141 & 0,213 \\
4 & 30 & 143 & 0,210 \\
5 & 30 & 142 & 0,211 \\
\hline & Rata-rata & $\mathbf{1 4 2 , 6}$ & $\mathbf{0 , 2 1 0}$ \\
\hline
\end{tabular}

Tabel 2. Hasil kalibrasi pada jarak depan $60 \mathrm{~cm}$

\begin{tabular}{|c|c|c|c|}
\hline $\begin{array}{l}\text { Data } \\
\text { ke-n }\end{array}$ & $\begin{array}{l}\text { Jarak Depan } \\
\text { Obyek }(\mathrm{cm})\end{array}$ & $\begin{array}{c}\text { Jarak Image } \\
\text { (piksel) }\end{array}$ & $\begin{array}{l}\text { Faktor } \\
\text { Pengali }\end{array}$ \\
\hline 1 & 60 & 75 & 0,800 \\
\hline 2 & 60 & 75 & 0,800 \\
\hline 3 & 60 & 75 & 0,800 \\
\hline 4 & 60 & 75 & 0,800 \\
\hline 5 & 60 & 74 & 0,811 \\
\hline \multicolumn{2}{|c|}{ Rata-rata } & 74,8 & 0,802 \\
\hline
\end{tabular}


Sedangkan penentuan jarak obyek depan dan bergeser ke samping kapal sesungguhnya sejauh 6 $\mathrm{cm}$ didapatkan jarak hasil rekaman kamera sejauh 68,8 piksel (Tabel 3) dan sejauh $8 \mathrm{~cm}$ didapatkan sejauh 199,4 piksel (Tabel 4).

Tabel 3. Hasil Kalibrasi pada Jarak Samping $6 \mathrm{~cm}$

\begin{tabular}{cccc}
\hline $\begin{array}{c}\text { Data } \\
\text { ke-n }\end{array}$ & $\begin{array}{c}\text { Jarak Samping } \\
\text { Obyek (cm) }\end{array}$ & Jarak (piksel) & $\begin{array}{c}\text { Faktor } \\
\text { Pengali }\end{array}$ \\
\hline 1 & 6 & 69 & 0,087 \\
2 & 6 & 68 & 0,088 \\
3 & 6 & 69 & 0,087 \\
4 & 6 & 69 & 0,087 \\
5 & 6 & 69 & 0,087 \\
\hline & Rata-rata & $\mathbf{6 8 , 8}$ & $\mathbf{0 , 0 8 7}$ \\
\hline
\end{tabular}

Tabel 4. Hasil Kalibrasi pada Jarak Samping $8 \mathrm{~cm}$

\begin{tabular}{cccc}
\hline $\begin{array}{c}\text { Data } \\
\text { ke-n }\end{array}$ & $\begin{array}{c}\text { Jarak Samping } \\
\text { Obyek (cm) }\end{array}$ & Jarak (piksel) & $\begin{array}{c}\text { Faktor } \\
\text { Pengali }\end{array}$ \\
\hline 1 & 8 & 200 & 0,040 \\
2 & 8 & 200 & 0,040 \\
3 & 8 & 199 & 0,040 \\
4 & 8 & 198 & 0,040 \\
5 & 8 & 200 & 0,040 \\
\hline & Rata-rata & $\mathbf{1 9 9 , 4}$ & $\mathbf{0 , 0 4 0}$ \\
\hline
\end{tabular}

\section{Konversi Warna}

Konversi warna digunakan untuk menyederhanakan pemrosesan juga meningkatkan keakurasian proses pengenalan objek yang ditangkap oleh kamera. Dengan mengubah format warna dari RGB ke format HSV (Hue Saturation Value) untuk didapatkan hasil segmentasi yang lebih baik.

\section{Segmentasi Warna}

Pada tahap ini dilakukan segmentasi warna untuk mendapatkan objek bola warna hijau. Untuk mendapatkan objek bola warna hijau yang terpisah dengan gambar selain bola, maka digunakan komponen warna yang hasilnya seperti yang terlihat pada Gambar 8 berikut ini:

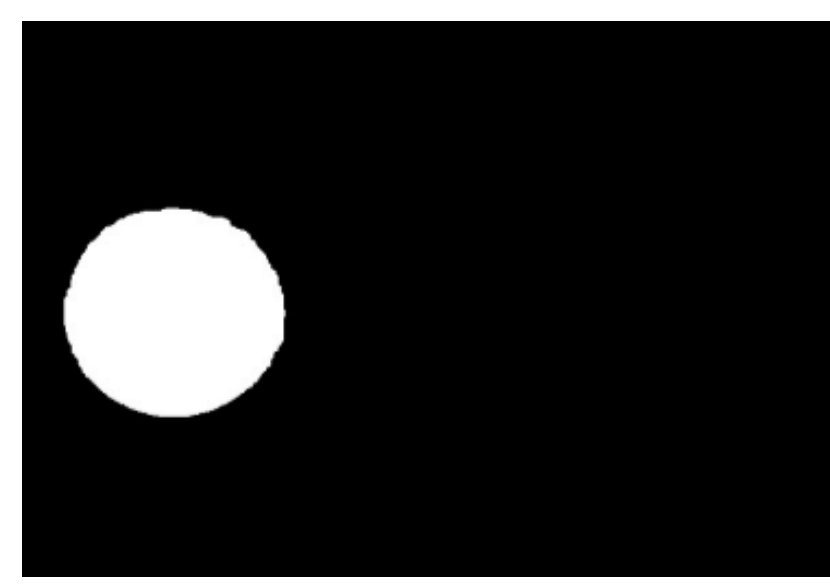

Gambar 8 Segmentasi warna

\section{Kendali Rudder}

Sistem kendali yang terdapat pada A-USV Geomarine 1 selain berbasis pada pengolahan citra, juga berbasis geopositioning dengan menggunakan receiver GNSS dan sensor ultrasonik sebagai deteksi objek penghalang di depan kapal.

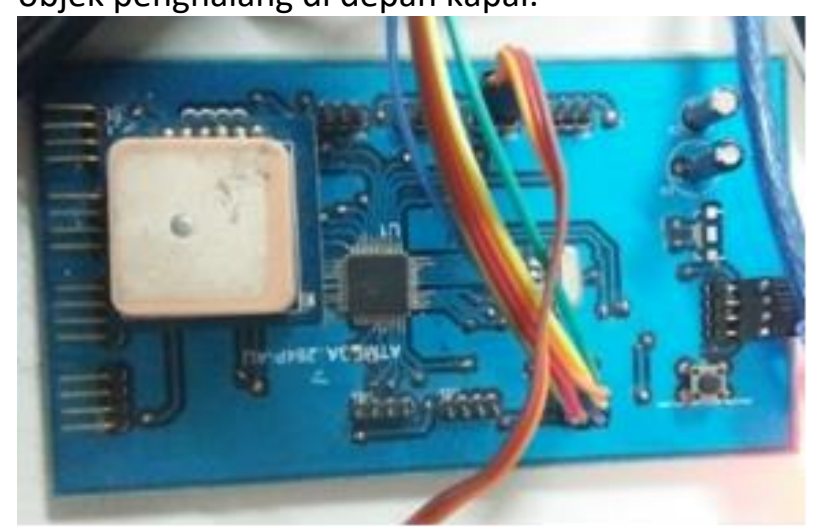

Gambar 9. Sensor Geopositioning

\section{Interface Sistem Navigasi}

Pada Gambar 10 dapat dilihat tampilan antar muka yang untuk melakukan kontrol terhadap sistem kendali A-USV Geomarine 1.

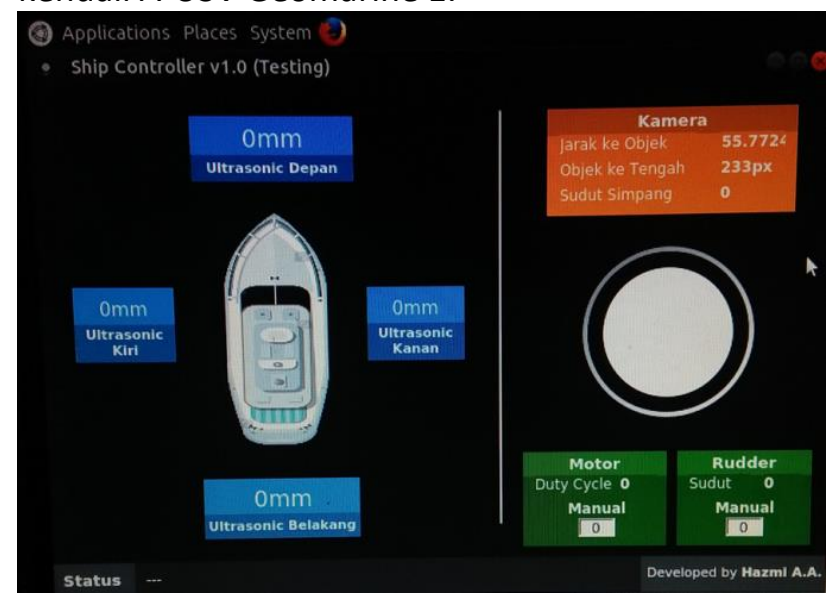

Gambar 10. Interface navigasi A-USV Geomarine 1 


\section{Percobaan Kapal A-USV Geomarine 1}

Percobaan kapal ini dilakukan di danau Departemen Teknik Geomatika pada tanggal 11 Desember 2017.

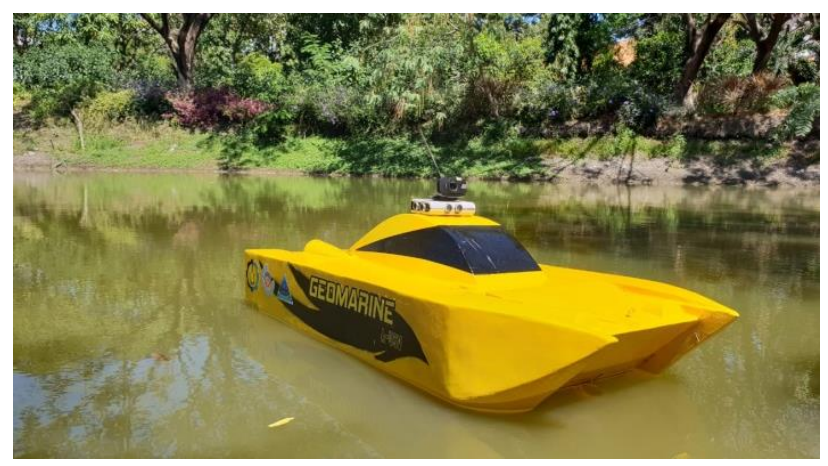

Gambar 11. Tampak samping kanan

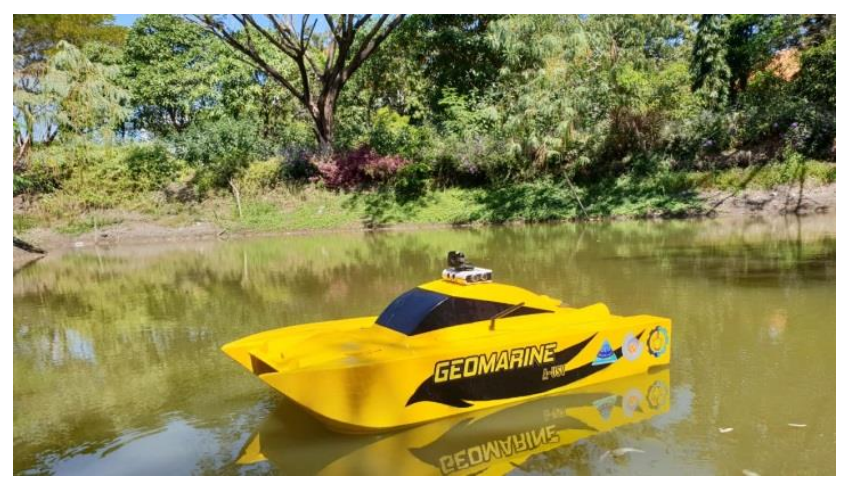

Gambar 12. Tampak samping kiri

\section{KESIMPULAN}

Wahana A-USV Geomarine 1 menggunakan model katamaran, dimana kapal katamaran memiliki dua lambung di kiri dan di kanan. Lambung ini berfungsi sebagai penyeimbang kapal sekaligus memberikan daya apung yang sangat baik untuk kapal.

Sensor akustik yang digunakan untuk survei hidrooceanografi yang terdapat pada wahana Geomarine 1 adalah single beam echosounder dan side scan sonar yang terintegrasi dengan Processing Unit dan alat penentuan posisi dengan menggunakan satelit (GNSS).

A-USV Geomarine 1 dilengkapi dengan sistem collision avoidance system dengan menggunakan sensor optik dengan menggunakan metode deteksi objek, untuk mencegah terjadinya tumbukan dengan benda-benda asing. Microcontroller yang dipasang di A-USV Geomarine 1 digunakan untuk menyimpan desain lajur survei dan sebagai masukan ke A-USV untuk bergerak secara mandiri.
Fitur Auto Home Return pada A-USV Geomarine 1 menjadi keunggulan tersendiri pada wahana ini dibandingkan dengan USV yang ada saat ini. Dengan fitur ini A-USV akan kembali ke titik awal apabila survei sudah selesai atau ketika baterai akan habis. A-USV Geomarine 1 juga dilengkapi dengan dua kamera. Kamera pertama berada di depan wahana untuk mengetahui keadaan di depan wahana secara real time. Kamera kedua ditempatkan di lambung wahana untuk melihat gambaran dasar perairan secara real time. Kedua kamera adalah kamera kedap air dan dapat berfungsi sampai dengan kedalaman $40 \mathrm{~m}$.

Untuk tahap selanjutnya, A-USV Geomarine 1 akan dikembangkan menggunakan sistem telemetri yang memungkinkan untuk mengirimkan data posisi dan kedalaman secara real time kepada pengamat yang berada di darat

\section{UCAPAN TERIMA KASIH}

Tim Peneliti mengucapkan terima kasih kepada Direktorat Inovasi, Kerjasama, dan Kealumnian ITS dalam mendukung penelitian ini.

\section{DAFTAR PUSTAKA}

Alberto, R., Pierluigi D. (2012). Autonomous Unmanned Surface Vessels for Hydrographic Measurement and Environmental Monitoring. https://www.fig.net/resources/proceedings/fig_ proceedings/fig2012/papers/ts04d/TS04D_roma no_duranti_6118.pdf. diakses pada 19 Juli 2017.

Newman, Paul. (2010). Unmanned Vehicle for Shallow and Coastal Waters. http://www.ths.org.uk/documents/ths.org.uk/d ownloads/shallowwater_auv_and_usv.pdf. diakses pada 19 Juli 2017)

Ni Made Rai R., Suwardhi D. (2014). Pembangunan Sistem Penentuan Posisi dan Navigasi Berbasiskan Sistem Unmanned Surface Vehicle (USV) untuk Survey Batimetri. http://jurnalonline.itenas.ac.id/index.php/rekay asa/article/view/476. diakses pada tanggal 18 Juli 2017.

Prabhu, T. (2016). Unmanned Surface Vehicle (USV) For Coastal Surveillance. https://www.iaeme.com/MasterAdmin/uploadf older/IJMET_07_03_002-2/IJMET_07_03_0022.pdf. diakses pada tanggal 18 Juli 2017. 